Notre Dame Law School

NDLScholarship

Journal Articles

Publications

2014

\title{
Law as Fact and as Reason for Action: A Response to Robert Alexy on Law's 'Ideal Dimension'
}

John M. Finnis

Notre Dame Law School, john.m.finnis.1@nd.edu

Follow this and additional works at: https://scholarship.law.nd.edu/law_faculty_scholarship

Part of the Jurisprudence Commons, and the Natural Law Commons

\section{Recommended Citation}

John M. Finnis, Law as Fact and as Reason for Action: A Response to Robert Alexy on Law's 'Ideal Dimension', 59 Am. J. Juris. 85 (2014). Available at: https://scholarship.law.nd.edu/law_faculty_scholarship/1065

This Response or Comment is brought to you for free and open access by the Publications at NDLScholarship. It has been accepted for inclusion in Journal Articles by an authorized administrator of NDLScholarship. For more information, please contact lawdr@nd.edu. 


\title{
Law as Fact and as Reason for Action: A Response to Robert Alexy on Law's "Ideal Dimension"
}

\author{
John Finnis*
}

\begin{abstract}
Robert Alexy's 2013 Natural Law Lecture, published in vol. 58 of this journal, presents law as having two dimensions, ideal and real, and thus a dual nature, to be elucidated by a conceptual analysis distinguishing between the observer's and the participant's perspective. It argues on this basis for a "non-positivist" theory of law that is "inclusive" in that it classifies some unjust laws as laws, but not all (and is thus not "super-inclusive"); it rejects the "exclusive non-positivism" that would treat every injustice in a law's making or content as excluding it from the class of valid laws. Gustav Radbruch's famous post-War formula-extreme injustice invalidates lawadopted in the jurisprudence of Germany's higher courts, is thus to be defended as expressing the inclusive non-positivism that articulates the best concept of law that can be constructed and defended as expedient. Alexy's 2013 article classifies the theory in Natural Law and Natural Rights as super-inclusive, but sees hopeful signs of inclusive non-positivism in some recent writings of its author. The present article argues that Natural Law and Natural Rights defends, in a sense, all three "non-positivist" positions, each in its proper place as a truth about unjust law: it is (from an observer's perspective) a fact; it is (from a participant's perspective) deprived by any significant injustice of law's generic and presumptive status (legal-moral validity) as a reason for action; and it is (from the perspective of particular participants in their circumstances) sometimes, despite its injustice and legal-moral invalidity, a source (by virtue of both the foregoing truths taken with other moral responsibilities and needs) of collateral obligations the extent of which is likely, often, to track, approximately, the results of applying the Radbruch formula. The article argues against Alexy's theoretical procedures both of conceptual analysis and of concept construction, regrets the "non-positivist/positivist" labeling, raises doubts about speaking of duality of dimensions and nature, and notes the significance of the 2013 article's further thesis that any injustice in a law impairs ("qualifies") its legal status.
\end{abstract}

Keywords: Alexy, Positivism, Radbruch Formula

This appreciative response to Robert Alexy's lecture (vividly defended and explicated by him in the discussion that followed it) will take account also of some of

* Biolchini Family Professor of Law, University of Notre Dame du Lac; Professor of Law and Legal Philosophy Emeritus, University of Oxford. Email: john.finnis@law.ox.ac.uk. 
his other publications bearing on the lecture's substance and argumentation. This will enhance the debate between us as an exploration of some fundamentals in the philosophy of law.

Part I questions first Alexy's structuring of legal theory around "the dual nature of law," that is, his thesis that law has both an ideal and a real dimension; and second his use of "conceptual analysis" and (not the same thing) conceptual "construction" to expound law's "ideal dimension." Parts II and III argue that his distinction between the observer's and the participant's perspectives is a better way into legal theory or philosophy, which is properly neither analysis nor construction of concepts, but a practical (albeit abstract, "theoretical") exploration of human needs and appropriate responses to them, responses to be articulated in concepts of law (and of related means of securing human goods and rights) that philosophical/theoretical reflection seeks to improve. Part IV enters a protest against the labels "positivist" and "nonpositivist." Part Videntifies the real "oddity" of the textbook debate about "necessary connections" between law and morality. Part VI engages with the Radbruch formula in the forms deployed in Alexy's 2013 article, and asks what can be said, in general, about how injustice-significant even if not "intolerable" or "severe"-affects law's status in the judgment of legal theory pursued, as it should be, from the practicallyreasonable participant's perspective. This final part of my response shows that all along my position on injustice's effects on laws has been, in Alexy's terms, only secondarily "super-inclusive" (as he thinks it primarily or essentially is) but primarily near the opposite end of his spectrum: "exclusive," though acknowledging restraining moral principles which direct legal theory to moral results that often approximate to his "inclusive non-positivism," albeit not always, and never for quite the same reasons as he refers to in "constructing" his Radbruchian position.

\section{Alexy on Observing the "Real Dimension of Law"}

The 2013 article begins "with the dual nature of law as comprising both a real or factual dimension and an ideal dimension." The ideas of "dual nature" and "dual dimensions" are elusive. But in part V of the article, some light is shone by the correlation of these dualities with another, the "two perspectives" (or viewpoints, or standpoints): the observer's and the participant's. In his The Argument from Injustice (1992/2002), Alexy chose the opposite order for his whole discussion of the connection(s) between law and morality: he began with the distinction between the observer's perspective and the participant's, and unfolded his arguments accordingly-on the observer's perspective from pp. 27 to 35, and on the participant's from pp. 35 to 81 . Only at the book's very end, after offering a definition of law ("from the participant's perspective"), ${ }^{2}$ does Alexy introduce the idea

1 Robert Alexy, "Some Reflections on the Ideal Dimension of Law and on the Legal Philosophy of John Finnis," American Journal of Jurisprudence 58 (2013): 97 (Abstract).

2 The Argument from Injustice: A Reply to Legal Positivism (Oxford: Oxford University Press, 2002), 127. This book is a translation by Stanley L. Paulson and Bonnie Litchewski Paulson of Begriff und Geltung des Rechts (Freiburg im Breisgau: Verlag Herder, 1992); the translation of the title would be The Concept and the Validity of Law or Law's Concept and Validity. 
of law's "dimensions," by remarking that legal systems or individual legal norms that fail to satisfy their own "claim to correctness" are "legally defective," and that "that is an expression of the fact that there is necessarily an ideal dimension to the law." 3 His subsequent decision to expound these problems in terms primarily of dimensions (ideal and real) is manifested, for example, in his "An Answer to Joseph Raz" (2007) ${ }^{4}$ and is formally elaborated in his "The Dual Nature of Law" (2010)..$^{5}$ I think the earlier treatment was clearer, and will give some attention to it below.

But it, too, is illuminated by Alexy's 2013 article:

[T] he observer is confined to social facts. That is not to say that his considerations cannot include considerations about what the participants whom he observes think the law ought to be. One might term such considerations about what persons think the law ought to be "indirect" or "third-person" considerations by contrast to the direct and first-person considerations of the participant. All this implies that from the standpoint of an observer, only the real dimension of law is of interest. ${ }^{6}$

Although the last statement does not logically commit Alexy to holding that law's real dimension consists of all those aspects of law, and of the law, that can be identified and affirmed from the observer's perspective, I have seen no sign that he thinks otherwise.

So it is important to inquire what aspects of law, and of the law (of a given community, say ours), are discernible from the observer's perspective (and thus are discernible, or at least not indiscernible, in a theory of law that aspires to be positivist). ${ }^{7}$ As Alexy conceives that perspective, it includes a full grasp of "the criteria for validity that are part of the legal system efficacious in" a given state. ${ }^{8}$ His observers are by no means "Legal Realists" who confine themselves to predictions of what the courts will do; nor are they mere historians of particular societies. Rather, Alexyan observers can accurately apply the given state's legal system's criteria of validity to assess official acts accurately as being (or not being) "authoritatively issued in accordance

3 The Argument from Injustice, 127. See below, $\mathrm{n} 70$.

4 Alexy, "An Answer to Joseph Raz," in Law, Rights and Discourse: The Legal Philosophy of Robert Alexy, ed. George Pavlakos (Oxford: Hart Publishing, 2007), 37.

5 Ratio Juris 23 (2010): 167-82.

6 Alexy, "Some Reflections," 103-4 (emphasis added). Alexy goes on: "For this reason, from the standpoint of an observer, positivism with one exception is correct." He thinks that an exception needs to be made because the positivist will-erroneously-count as a legal system even systems that make no "claim to correctness." But as the example of Raz shows, self-styled positivists may well agree with Alexy that a system that makes to claim to correctness (Richtigkeit. as Raz would say, to legitimacy) is not legal, and would regard this agreement neither as carrying them out of the observer's perspective nor as introducing into law an "ideal dimension", since the claim is not the less real for being mistaken. (Raz holds that the claim, though conceptually necessary for a system to be legal, is generally false, as it stands, since in moral truth, he thinks, there is no general moral obligation, even prima facie, to obey the law; and Alexy for his part rightly says, in The Argument from Injustice, 34, that a system that makes such a claim may yet be "without a doubt unjust in the extreme.")

7 See below, text at n37.

8 The Argument from Injustice, 30. 
with the law" of that state and system. ${ }^{9}$ And, as Alexy's 2002 discussion concludes, "Radbruch's argument from injustice is not acceptable from this standpoint." 10 For:

[I]t is clear that in the observer's perspective, the expression "law" can be used in such a way that, as applied to individual norms, not only is a classifying ${ }^{11}$ inclusion of moral elements in the concept of law not conceptually necessary, it is also conceptually impossible... From the perspective of an observer, Radbruch's connection thesis cannot be supported by appeal to a conceptually necessary connection between law and morality. ${ }^{12}$

Or as the 2013 article puts it shortly: "the Radbruch formula ... is incorrect from the standpoint of the observer." 13

Thus Alexy accepts that there is a sense of "the law" and of cognate or correlated terms such as "legally valid" and "legal validity" such that they can be applied with full accuracy to monstrously unjust laws. And that is all that Natural Law and Natural Rights means when it says (as he reports), ${ }^{14}$ that

The [natural law] tradition explicitly (by speaking of "unjust laws") accords to ${ }^{15}$ iniquitous rules legal validity, whether on the ground and in the sense that these rules are accepted in the courts as guides to judicial decision, or on the ground and in the sense that, in the judgment of the speaker, they satisfy the criteria of validity laid down by constitutional or other legal rules...16

For if observers can be speaking accurately when they call monstrously evil laws legally valid, as Alexy accepts they can, any sound legal theory must have room for

9 Ibid., 29. I am not sure that this can be reconciled with the statement in "An Answer to Joseph Raz," 46 that:

The observer, qua observer, can only describe the practice of the Constitutional Court and the debate on which the Court is engaged. He cannot engage in argument on the question of which answer is legally correct. As soon as he does that, he ceases to be an observer and becomes a participant.

10 The Argument from Injustice, 31.

11 [That is, as opposed to merely "qualifying." See "Some Reflections," 104: "The effect of a classifying connection [between law and morality] is the loss of legal validity. By contrast, the effect of a qualifying connection is legal defectiveness or incorrectness that does not, however, undermine legal validity."]

12 The Argument from Injustice, 30. Note that one of Alexy's arguments (ibid., 29-30) in support of this thesis about observers is that a foreign jurist writing a law review article (in, say, 1942) about the Nazi legal system would count the Ordinance of 25 November 1941 as part of German law, and the deprivation of citizenship/nationality as "according to German law" (26), "in accordance with the criteria valid in Germany" (30). On the ordinance, see text at nn72 to 75 below.

13 Alexy, "Some Reflections," 110.

14 Ibid., 105.

15 As I note in the Postscript to Natural Law and Natural Rights, 2d ed. (Oxford: Oxford University Press, 2011; 1st ed., 1980; hereafter NLNR), 476, this phrase "accords to" is loose; rather: "The tradition accepts that iniquitous rules may satisfy the legal system's criteria of legal validity, and where they do, it does not seek to deny that fact..." (emphases added). Alexy, "Some Reflections," 109, partly quotes and partly paraphrases the remainder of my Postscript comment here; I do not think his paraphrase altogether accurately conveys my point, but need not pursue the matter. He is right to say (110) that the Postscript comment does not make a Radbruchian point.

16 NLNR, 365. 
the same accurate propositions, whatever propositions it may go on to add by reference to considerations not available to the mere observer qua observer. ${ }^{17}$ To make such room is not to be "super-inclusive" (so far as that term has connotations of excess), for to fail to make room for true propositions would be under-inclusive.

Notice, moreover, how inclusive the observers' point of view, as conceived by Alexy, ${ }^{18}$ really is. These observers can not only report all the criteria of decision that courts and lawyers actually use in some society, but can apply these established criteria to facts not yet considered by any lawyers or courts. Presumably, in applying established criteria, competent observers can apply established methods of argumentation. In short, they can do everything that a competent lawyer or judge who is a participant can do, other than actually make decisions that count as legally efficacious (since to do so would be to be participants as well as observers). I have not seen Alexy challenging Hart's thesis ${ }^{19}$ that, since participants (say judges) may have any of many viewpoints besides a moral viewpoint, the specifically legal point of view is precisely-or corresponds precisely to-the viewpoint of an observer who, like Alexy's observer, understands all the items that any participant regards as established law (all the rules cognizable by reference to an officially accepted rule of recognition, together with any principles accepted in official practice). But Alexy's preference for "non-positivism" depends on making (implicitly if not explicitly) just such a challenge. In the absence of such a challenge, legal positivists can rest easy in the thought that their method allows them to see and understand all that law really is-the whole "real dimension" of law including the participant's perspective, and the participants' possible interest in "ideals," in so far as such participants" perspective and idealistic interests and purposes have actually yielded the set of enactments, constitutions, precedents, customs and official practices we call the law of some given state. What more, a legal positivist might say, need a theory of law undertake to discuss? Why concede

\footnotetext{
17 Note that Alexy, "Some Reflections," 110 says that "the observer is free to contest any moral duty to obey or to apply law..." But one who contests (or affirms) moral duties is not doing so qua observer; whether or not he is strictly a participant in the legal system discussed, he thereby abandons the descriptive for the normative, the descriptive for the practical; he addresses not the world as it is but the world as it ought to be (so far as the moral choices, or types of moral choice, under discussion could affect it). What Alexy says about participation in legal argument applies a fortiori to participation in moral argument, about law or anything else:
}

The observer, qua observer, can only describe the practice of [say] the Constitutional Court and the debate [about a disputed legal issue] in which the Court is engaged. He cannot engage in argument on the question of which answer is legally correct. As soon as he does that, he ceases to be an observer and becomes a participant.

Alexy, "An Answer to Joseph Raz," 46.

${ }^{18}$ But here I prioritize some over others of Alexy's statements about the observer: see $\mathrm{n} 9$ above, quoting the passage requoted in $\mathrm{n} 17$ above.

19 See H.L.A. Hart, The Concept of Law 3d ed. (Oxford: Clarendon Press, 2012; 1st ed. 1961), 198, 203, 226; Essays on Bentham (Oxford: Clarendon Press, 1982), 153-61. For a challenge to Hart on this, see NLNR, 13-18; and Finnis, "On Hart's Ways: Law as Reason and as Fact," Philosophy of Law: Collected Essays of John Finnis [CEJF] vol. IV (Oxford: Oxford University Press, 2011), 249-50, 256. 
that "law has an ideal dimension"-the assumption" ${ }^{20}$ with which Alexy, in 2013, begins his argument about law and morality?

\section{Alexy's Conceptual-Analytic Unfolding of "the Participant's Perspective" (and of Law's "Ideal Dimension")}

It is right to try to understand law from the perspective of participants in the reaching of decisions (choices) about whether and what laws to make, to recognize, to apply and to comply with; and I agree that this perspective on the law is primary, and the observer's secondary (and indeed derivative).

But Alexy's method of explaining law from the participant's perspective differs widely from mine. His is conceived primarily ${ }^{21}$ as conceptual analysis or a search for conceptual necessities. Mine is not a matter of conceptual analysis, but rather of understanding how basic human ends_needs and goods-and appropriate means come together in a critically justified understanding-concept-of law. That is to say: this process of critical practical reflection-not to be confused with the "construction" and adoption of an "expedient" concept ${ }^{22}$-proceeds by way of articulating and testing substantive claims about what practical reason (ableness) requires of anyone and everyone, requirements that include a need for law as a characteristically indispensable means to securing the common good of justice and peace, by coordination achieved by way of authority of an appropriately rule of law kind. I do not think that conceptual analyses yield significantly useful fruits in legal, political or moral philosophy. ${ }^{23}$ In particular, discussions of what is conceptually possible or impossible, or again of what is or is not conceptually necessary, are virtually always fruitless.

\section{${ }^{20}$ Alexy, "Some Reflections":}

The starting point in my defense of the necessity thesis is the assumption that law has a dual nature...that law necessarily comprises both a real or factual dimension and an ideal or critical one. The real dimension consists of authoritative issuance and social efficacy, the ideal refers to moral correctness.

21 The Argument from Injustice, 20-23, 40, 42, 62 appears to me to hold that there are also "normative arguments or considerations of expediency [Zweckmässigkeit]" (22) concerning the concepts to be adopted in theorizing about, and defining, law; but these are envisaged as supplementary to the tracing (where possible) of conceptually necessary connections and definitions (23). Zweckmässigkeit might also be translated as purposiveness, or usefulness. Note: the conception of normativity and of "normative necessity" articulated at p. 21 n 40 is extremely voluntaristic: "that something is normatively necessary means nothing other than that it is commanded [geboten]." But I shall leave this voluntarism out of account. See further the next footnote.

22 One part of Alexy's work does something apparently similar, insofar as it consists in "expedient or adequate [zweckmässige oder adäquate] concept formation that is justified by normative arguments" about the Radbruch formula, the debate about which, "there is widespread agreement today," "cannot be decided on the basis of analytical or conceptual arguments alone": The Argument from Injustice, 40. But these normative arguments are not so much about the moral need for law, and law's consequent essential or central-case features, but rather about whether or not it is expedient or inexpedient to adopt a boundary-line between the legally valid and the legally invalid by reference to injustice or at least severe or intolerable injustice. This sort of devising of a conceptual boundary on normative grounds treats as quasi-central-because conceptual, at least in its product-what I regard $(N L N R, 351)$ as "a subordinate theorem." See further at $\mathrm{n} 77$ below.

${ }^{23}$ See, e.g., $N L N R, 273,278-9,426$. 
An example: Alexy, much like Raz, ${ }^{24}$ holds the thesis that it is conceptually necessary that legal systems claim, through their officials, to be morally (as well as legally). "correct" (richtig. Raz says "legitimate"). As he says in his 2013 article: for a legal system to abandon this claim "would represent a transition from a legal system to a system of naked power relations, ${ }^{25}$ in other words, to something that is, necessarily, no legal system." 26 Knowing that I have argued against this thesis in, for example, the Postscript to Natural Law and Natural Rights, ${ }^{27}$ Alexy responds, simply: "If this means that a legal system can forbear from claiming to be morally correct, the point must be rejected." If readers wonder why my point "must be rejected," they should look to the earlier part of the same key paragraph opening the article's part III, "The Necessity of the Claim to Correctness." Here Alexy unfolds his argument, deployed also in his 1992/2002 book and his 2010 article and other works: it would (i) be "performatively self-contradictory" for a constitution to declare the state "a sovereign and unjust republic," for this (ii) would implicitly contradict the claim implicitly (but necessarily) made by every constitution, that it institutes a just ("morally correct") regime.

Now such a constitutional declaration would certainly be extremely odd. But the conclusion (i) that it would be performatively contradictory or self-refuting depends on the premise (ii) that constitutions necessarily claim, at least implicitly, that they (and the regime they institute) are just - which is precisely the question in issue. And there is nothing odd about a constitution which to all appearance says nothing-makes no claim-about its justice (or injustice), but simply articulates its provisions for the exercise of legislative, executive and judicial powers and for the supremacy of constitutionally valid laws over competing laws, sources of law, and purported exercises of power. So Alexy's argument, which helps itself to its conclusion as a premise, leaves intact the competing argument that I recently put as follows: ${ }^{28}$

It seems entirely possible for a regime to proclaim:

Our law, which satisfies all the (say) Hartian criteria (primary rules restricting violence, theft and fraud, secondary rules of recognition, change and adjudication, etc.), imposes legal duties and confers legal rights that have nothing to do with moral rights. Our law imposes legal obligations that are not moral obligations, and has nothing to do with justice in the moral sense etc., but is instead a structure of

${ }^{24}$ But for Alexy the thesis is more significant and central to his theorizing about law than it is for Raz:

The argument from correctness is the basis of the other two arguments [about the relation between law and morality], that is, the arguments from injustice and from principles. It says that individual legal norms and individual legal decisions as well as legal systems as a whole necessarily lay claim to correctness.

The Argument from Injustice, 35-6 (emphasis added).

25 Here he cites Alexy, "Law and Correctness," Current Legal Problems 51 (1998): 213-4.

26 Here he cites Alexy, The Argument from Injustice, 32-5.

27 Here Alexy cites $N L N R, 432 \mathrm{n} 13$, where, to distinguish my position from Raz's, I remark: "it is possible that some legal systems abstain from claiming to be morally obligatory."

28 "Reflections and Responses," in Reason, Morality and Law, ed. John Keown and Robert P. George (Oxford: Oxford University Press, 2013), 538 (response to N.E. Simmonds; footnotes edited). 
ordered power designed to pursue our sectional purposes. We as regime will mercilessly enforce this law.

I see no compelling reason for saying that this "would not be a legal order" (still less why it is conceptually impossible). It is simply very deviant, since being for common good, including justice and human rights, is central to law-is at the core of law as an idea. The deviation is possible because, once legal thought has become conscious of its own source-based character, and equipped with (and dependent on) legal rules about what counts as such a source, one can distinguish sharply between legal right(s) and moral right(s), and so forth. In central-case legal systems, of course, all these distinctions and technical devices ${ }^{29}$ remain in the service of moral rights and purposes-not least, of doing justice according to law-and it is both an aspiration and an assumption that legal and moral obligations should not and properly do not diverge except in marginal and "extraordinary" cases. So: wicked and exploitative regimes will no doubt tend to find it more convenient and effective to pretend that their law serves common good, justice, and moral rights... ${ }^{30}$ But that is only one kind of deviant case; the other, more shameless, less duplicitous kind (as I have postulated it [in the imaginary declaration above]) remains possible.

This passage refutes, I think, Alexy's claim that a legal system that ceased to claim "correctness" (Richtigkeit, rightness, including justice), at least implicitly, would thereby, necessarily, transit "from a legal system to a system of naked power relations, in other words, to something that is, necessarily, no legal system." 31

For the system described in my imaginary rulers' declaration above is not one of "naked power relations," but of power relations regulated by Hartian primary and secondary rules conferring legal rights and duties, including legal rights to be treated according to the rules, rights which will be enforced against individual officials as well as against mere subjects. Hence it is not like the "bandit system" imagined by Alexy in the page of The Argument from Injustice that he cites to explain why "naked power relations" are "necessarily, no legal system"- the page on which he says that a bandit system is "for conceptual reasons alone" not a legal system. ${ }^{32}$ To establish this point, Alexy in 2002 went on to postulate a transition from the bandit system to a system he calls a "governor system," a transition that he says is "conceptually" a transition to legal system. He characterizes the transition as involving two features: (a) the rulers "continue to exploit their subjects, but their acts of exploitation proceed according to a rule-driven practice," and (b) "everyone is told that this practice is correct because it serves a higher purpose, say, the development of the people." 33 Unfortunately, Alexy then asserts that it is (b) not (a) that makes the conceptual transition from non-legal to legal. ${ }^{34}$ Thus he

29 ... On law as a fourth-order, technical kind of object (properly in the service of third-order, moral purposes), see CEJF I.14 ("Legal Reasoning as Practical Reason"), 219-20; CEJFIV.5, 111, 148-9, 155; IV.6 166, 169-72; IV.14, 326.

30 ... as I [postulate] in NLNR, 274.

${ }^{31}$ Alexy, "Some Reflections," citing Alexy, "Law and Correctness," 213-4, and The Argument from Injustice, 32-35.

32 The Argument from Injustice, 33.

33 Ibid., 33-4.

34 Ibid., 34. Here Alexy seeks to make (b) do all the conceptual work, by saying that the non-legal "bandit system" did include the feature that "here general rules of some kind prevail." But the point 
once again simply begs the question against the thesis that nothing conceptually excludes calling an exploitative system legal if the exploitation proceeds "according to a rule-driven practice," even if the exploitative purpose is not masked by any claims to justice.

Conceptual-analytical arguments regularly become, like the foregoing, a vexatious contest between rival intuitions about concepts supposed to be already fully and rightly established, and about more or less imaginary scenarios supposedly illustrative of the boundaries of those established concepts. By their nature, such arguments focus on "marginal" cases and supposed "transitions" between whole classes or classifications (concepts), and on language (established linguistic usage) rather than on the issues of reality and value that are really at stake, and really of interest. Far more fruitful are reflections and arguments about the central kinds of case that come into view when one looks to the main human realities and the main forms of intrinsic human wellbeing and deprivation-in other words, to characteristically human needs - and to the kinds of choice (and thus kinds of practice and institution) intelligently and reasonably responsive to these needs. Exploration of these ends, predicaments, and means appropriate to securing these ends in these predicaments, will yield concepts that will doubtless be extensively reflected in established language and concepts but may amplify, clarify and adjust those established idioms and concepts. The prospect of such conceptual improvements is what makes theorizing (philosophizing) attractive and potentially fruitful. But the conceptual clarifications and improvements, when achieved, are in every way secondary to the realities and values that theory exists to grapple with, understand, and (when, like legal theory, it is the theory of a kind of practice) deploy.

The theory or philosophy of law, then, is best done by tracing the human needs to which law-legal systems and the rule of law-is a uniquely appropriate kind of response. These needs constitute the basic reasons for action which are available to make law a set of reasons for action. One main human need is (to cut a long story short) the need to be treated justly, a need the contours of which can only be assessed by considering the wellbeing of individuals-all of us-in the context of the communities to which we belong, as members but each of us an end in oneself (since human goods are to be respected as the goods of persons). So law, positive law, is needed largely if not wholly as the appropriate response to the need for justice. So of course positive law should be just, and should claim to be just, and be such that the claim is true not false. This is a normative need, and any conceptual necessities and historical typicalities that may be established by the formation of concepts and practices in line with this and other normative needs are necessities and typicalities derivative from these normative needs or necessities, needs and necessities that not surprisingly are reflected more or less adequately by those established concepts.

of (a) was that the rules prevailed not only as between mere subjects but also in relations between subjects and officials, at least to the extent that subjects could appeal to the rules in their dealings with officials and not be simply ignored or derided when doing so. 
So the participant's view (to use Alexy's term) has, I think, unequivocal priority in theorizing about law, theorizing that should proceed by looking not for conceptual necessities but rather for human needs and appropriate responses.

This does not render legal theory a matter of ideals rather than realities. Practical reasoning is irrational unless it pays scrupulous attention to facts and realities. Every piece of practical reasoning, whether moral in kind or not, contains at least one normative premise (about some good) and at least one factual, non-normative premise (about the conditions under which, in fact, that good is more or less likely to be attained, advanced or respected, or lost, damaged, impeded, or contemned). Practical philosophy, adequately conceived, gives guidance both about the genuine goods at stake in human existence and action, and about the kinds of factual conditions characteristically promotive of or threatening to those goods. Some of these factual conditions are features of human nature and the human predicament independent of (or at least, prior to) human choices. Others are conditions more or less dependent for their existence on human choices of which they are the result (intended, or unintended but more or less foreseeable). Hence a sound, fully practical-and therefore fully practically-reasonable and thus also fully morallypurposeful-legal philosophy will include all the attention to facts and realities that a "positivist," purely descriptive legal philosophy might include.

And the practical legal philosophy will include those facts and realities with more critical awareness of why it is attending to these facts and realities and not to others. Chapter I of Natural Law and Natural Rights shows, I think, the inadequately critical character of some philosophies of law that intend to be positivist; chapters III to XII show the unfolding of a full theory of positive law on the basis of a morally substantive theory of individual and social life, a theory displayed as moral by being fully in line with requirements of practical reason(ableness).

\section{Legal Theory as (Abstract) Practical Reasoning about Human Goods, Needs and Rights}

To repeat, the philosophy or theory of law is best done from "the participant's perspective," understanding this as the perspective of the fully reasonable participant. As I try to show in Natural Law and Natural Rights and other works (and as the mainstream from Plato and Aristotle through Aquinas holds), the perspective of the fully reasonable person is also the moral perspective. ${ }^{35}$ For morality is best (i.e., most reasonably) understood as what reason demands and directs in the open horizon of the whole of human life; what the principles of practical reason taken integrally demand and direct is articulated in the principles and precepts rightly called moral precepts or morality. So the participant's perspective is centrally also a critically moral perspective, and the philosophy of law explains that human communities have a strong presumptive moral responsibility to introduce positive law and to live by and under the rule of law, and to make and keep their positive law in line with justice (that is, with the principles that are morally

35 See NLNR, 101, 126-7, 129, 433. 
binding independently of any ratification of them by practice, enactment, or judicial declaration-ius cogens) even when, as purely positive law, it goes far beyond what the principles of justice antecedently require or entail. ${ }^{36}$

Once laws are in place, the practice of thinking and acting more or less in accord with them can be observed (perceived and described). So there can be an observer's perspective on actual or past laws. But this perspective has little or no theoretical significance, since its criterion of correctness (accuracy, truth) is consistency with the describable facts of opinion, language and practice in some particular time(s) and place(s). Accounts of laws and legal systems from a purely descriptive viewpoint lack generality or theoretical character. Any aspiration to provide a descriptive general account, or theory, will be dependent, for its accomplishment, on adopting some participant's viewpoint as the criterion for selection and formation of concepts with which to give the account, or state the theory. The only participant's viewpoint that it is philosophically justifiable to adopt is the reasonable (and thus morally sound) participant's. That was the argument of chapter I of Natural Law and Natural Rights, and it is a main answer to the positivist's question ${ }^{37}$ about whether anything beyond oberservation/description is needed to do sound theory.

A law exists as a fact because it has been envisaged as a reason by a law-maker who has the capacity to make it (by enactment or binding precedent) become a reason for action for its subjects. Given the flow of time, we can say that law has a "double life," (a) as reason and (b) as fact-the fact of being now and at relevant times in the past accepted as a reason for action by judges, officials and other subjects. ${ }^{38}$ Moreover, the positivity of law means that its holding as a reason has as one among other premises or bases the fact of (or facts involved in) its positing.

\footnotetext{
${ }^{36}$ See e.g., NLNR, ch. X (Law), especially X.7 (Derivation of "Positive" from "Natural" Law)

37 See above, text at $n 7$.

${ }^{38}$ More fully:
}

\begin{abstract}
What makes a rule of our law a rule of our law is always this: that some past act of constitution-making, enactment, and/or adjudication is treated by us now as sufficient reason for accepting that that action laid down or confirmed a rule, and that the rule it laid down or confirmed then settled, and now settles for us (some main and often decisive aspects of), how we are going to act now in ways that strongly affect the future well-being of one, some, or all of us. This reference to - or connectedness to-the past doubles up, too. For many of those positive-law rules of ours are treated by us as the decisive reason for us to treat past agreements, settlements, and other more or less private or non-official arrangements as now legally effective and decisive for the future well-being of some, perhaps very many persons among us. The dispositions and willingness referred to by these phrases "treated by us" and "for us to treat" are the factual, "ontological" basis or substance of our law. Without such a basis, in present or prospective fact, the reasons for treating a rule of our law as sufficient reason for action cease to be sufficient.
\end{abstract}

Finnis, "Reflections and Responses," 519. Again, ibid., 554n:

$[\mathrm{L}] \mathrm{aw}$ is a relationship between persons in the present, a relationship shaped by the systematic willingness of these present persons to treat themselves as in a relationship to persons (not excluding themselves) in the past of their community, and to make this backward reference to originating sources in the interests of future persons of this same community.

And earlier, NLNR, 269:

$[W]$ e can say that legal thinking (i.e. the law) brings what precision and predictability it can into the order of human interactions by a special technique: the treating of (usually datable) 
Like Alexy's "real and ideal dimensions," the statement that law "has a double life" is metaphorical. Everything I have said so far has been meant to show (a) why this metaphor is preferable to Alexy's, and (b) how far the idea of law's double life, as I understand it, approximates to the idea that law can be studied from a participant's or from an observer's perspective, but also (c) how complex are the relations between viewpoints given the complexity of practical (participant's) reasoning as necessarily involving both normative/evaluative and factual premises. To consider law (whether in general or as the law, our law) precisely as reasons rather than as facts involves paying full attention to many facts relevant to judging that one's law-related actions (as legislator, judge, or other subject) are based on sound reasons for action. Some of the relevant complexities of the rationally required attention to facts-extensive attention, but still to some of the facts and not to others - can be studied in the essay in which I found myself provoked to use the metaphor of law's double life as reason and fact, an essay reflecting on the legal and litigated question whether it was a mistake "of law" or "of fact" for X and $\mathrm{Y}$ to enter into a contract of a kind that, at the time, was regarded by virtually all competent lawyers as intra vires but that, some years later, was judged by the highest court to have been ultra vires and consequently void ab initio. ${ }^{39}$ Was the mistake made by the legal advisers who advised in 1981 that the contracts were valid a mistake about what the law's reasons (rules and principles) all things considered (in 1981) affirm, entail and settle, or rather a mistake only about what in fact the courts in 1991 would in the event determine to have been the law in 1981? Surely it was about both. ${ }^{40}$

\section{Against "Positivist or Non-Positivist"}

A sound legal philosophy is not well described as "non-positivist." The disjunction between "positivist" and "non-positivist" concedes to self-described positivists the assumption that theirs is the default position—or at least a default position

past acts (whether of enactment, adjudication, or any of the multitude of exercises of public and private 'powers') as giving, now, sufficient and exclusionary reason for acting in a way then 'provided for'. In an important sense the 'existence' or 'validity' of a legal rule can be explained by saying that it simply is this relationship, this continuing relevance of the 'content' of that past juridical act as providing reason to decide and act in the present in the way then specified or provided for. The convenience of this attribution of authoritativeness to past acts is twofold. The past is beyond the reach of persons in the present; it thus provides (subject only to problems of evidence and interpretation) a stable point of reference unaffected by present and shifting interests and disputes. Again, the present will soon be the past; so the technique gives people a way of now determining the framework of their future. (Emphasis added.)

39 Kleinwort Benson v. Lincoln City Council [1998] U.K.H.L. 38, [1999] 2 A.C. 349, discussed in Finnis "Adjudication and Legal Change," CEJF IV, essay 20, originally "The Fairy Tale's Moral," Law Quarterly Review 115 (1999): 170-5.

40 See ibid., touching on (without fully answering) such resultant questions as: Should the difference between the two mistakes affect liability to make restitution of moneys paid and received on the mistaken assumption that the contracts were valid? Should this question be affected by the fact that English courts had since before 1802 been holding that the difference between the types of mistake affects the restitutionary claim? If so, should that effect be altered by the 1998 decision of the highest court to treat that 200 -year-old legal doctrine as having been all along incorrect? 
or option-in legal philosophy. But that assumption is historically mistaken and theoretically ungrounded.

The positivity of law is fully noticed, explained, and justified in the mainstream of legal philosophy by thinkers, such as Aquinas, whom no-one wants to call positivists. Self-described legal positivism is, in simply historical terms, a johnnycome-lately position or set of positions (actually more or less incompatible with each other). ${ }^{41}$ And those positions are indefensible to the extent that they contradict the historical mainstream positions taken up and, I hope, somewhat clarified in Natural Law and Natural Rights. One of the inherent weakness of an important "positivist" position is indicated in a couple of paragraphs of the Introduction to my Philosophy of Law essays (2011), ${ }^{42}$ commenting on Joseph Raz's paradigmatic "positivist" thesis that:

All law is source based. A law is source-based if its existence and content can be identified by reference to social facts alone, without resort to any evaluative argument. ${ }^{43}$

To this piece of theory-not itself an observation of fact-I responded:

the easygoing phrase "identified by reference to social facts alone" offered as a translation of "source-based," is doubly problematic.

For, first, no one ever can rationally treat a fact alone as giving reason for anything, let alone something as demanding and choice-restricting as a law. There must always be some "evaluative argument" for treating any fact or combination of facts as a "basis" for identifying a proposition as obligation-imposing or in some other way directive or normative. What reason have $I$ as citizen or judge for identifying certain utterances as now legally directive (for me or for anyone else), utterances made on some past occasion by an assembly styling itself constituent or legislative or a tribunal styling itself a superior court of record? The answer must, to make sense, refer to some good or goods (human need or needs) that will be promoted if I make the identification or prejudiced if I do not. ${ }^{44}$

And second, in no legal system responsive to human needs do citizens, judges, or other officials look to the bare social fact of a past legislative act or act of adjudication. Always the reference is to such acts in their intra-systemic context. And that context is,

${ }^{41}$ Analogous positions can be detected as prominent at the dawn of philosophizing about law: see "Legal Philosophy: Roots and Recent Themes," CEJF IV: 158-9, on the position of Alcibiades in Xenophon's Memorabilia I.2 (and on the critique of such positions in the (pseudo-)Platonic Minos 313b-317d).

42 "Introduction," CEJF IV: 4-5; see also "A Grand Tour of Legal Theory," in ibid., 100-101.

43 Raz, Ethics in the Public Domain (Oxford: Oxford University Press, 1994), 211. Likewise Raz, Between Authority and Interpretation (Oxford: Oxford University Press, 2009), 386.

44 [fn. 9 in the original]

Of course, once a community has, with sufficient stable consensus, treated a set of laws as sufficient reasons for action, historians, sociologists, and other observers (including its own members) can refer to that fact by stating that those laws exist as laws of that community. But as is plainly acknowledged in Raz, Practical Reason and Norms (London, 1975), 171-7 esp. 172 and Raz, "Promises and Obligations" (1977) at 225 (see NLNR, 234-6), such statements are altogether parasitic upon the basic and primary thoughts and statements about the existence, validity, and obligatoriness of laws, viz. the thoughts and statements of those subjects and officials who thereby express their judgment that, in the factual situation they presuppose or identify, these are laws giving them sufficient legal and moral reason(s) to act in the way they validly direct (reasons over and above avoidance of immediate sanctions). 
first and foremost, a set of propositions identifying necessary and sufficient conditions of validity both of legislative and adjudicative acts and of the legal rules identifiable by reference (directly but in part!) to those acts. And such validity conditions pertain not only to the circumstances and form of those acts but also to the consequent rules' persistence through time as members of a set of propositions whose membership changes constantly by addition, subtraction, amendment, clarification, explanation, and so forth. Contributing both rationale and countless details of content to this complex of propositions and intellectual acts (juristic interpretation), will be found "references" —often silent but detectable by inference - to the desirability of coherence here and now, of stability across time, of fidelity to undertakings, respect for legitimate expectations, avoidance of tyranny, preservation of the community whose laws these are (and of its capacity for selfgovernment), protection of the vulnerable, incentives for investment, maintenance of that condition of communal life we call the Rule of Law, and many other "evaluative arguments." Of course, these references, whether tacit or expressed, are themselves social facts, which like all other social facts could, instance by instance, be given a value-free, descriptive report. But their pervasiveness witnesses to the rational need for them. Only by looking to such desirabilities can there be a sensible response to the plain questions to which a consistent, rigorous positivism ${ }^{45}$ is so unresponsive: Why treat past acts or social facts as sources of guidance in deliberation and reasonable decision-making today? How can any social fact validate? Or bind? And why these facts, not those? ${ }^{46}$

That may suffice as one warrant for holding, as I do, that the core proposition of a paradigmatic self-identified legal positivism lacks the stable responsiveness to questions needed to be entitled to count as a proper candidate or option in legal theory or philosophy; and that "non-positivist" is therefore scarcely a satisfactory self-description for would-be alternative or contrary positions. Chapter I of Natural Law and Natural Rights offered a different critique; chapter II showed the errors made by standard "positivists" about natural law theory; and chapters III-XII try what I think is the best strategy for overcoming the mistakes of selfstyled positivists, namely, a showing that everything sound in a philosophical account of positive law can be given in the course of an account of law's moral necessity and moral limits.

\section{What is Odd about the Textbook Debate}

The 2013 article misunderstood my remarks ${ }^{47}$ about "the sheer oddity of the 'debate' that still dominates the construction of textbooks and distracts the

45 [fn. 10 in original]:

Positivists themselves are another matter: see at nn. 19, 20 below. On this incoherence of a consistent, rigorous legal positivism with the explanatory task it sets itself, see secs III, IV, and VII of essay 5, or ["On the Incoherence of Legal Positivism", Notre Dame L Rev 75 (2000) 1597-1611], which begins:

Legal positivism is an incoherent intellectual enterprise. It sets itself an explanatory task which it makes itself incapable of carrying through. In the result it offers its students purported and invalid derivations of ought from is.

46 "Introduction," CEJF IV: 4-5.

47 Ibid., 7. 
attention of students." Alexy thought that I was pointing to that oddity in the sentence immediately following the one just quoted, the sentence that runs "It is said to be a debate about whether there is any necessary connection between law and morality." So he sprang to defend the debate, and his article's main point is to explain that, and why and how, there is indeed such a necessary connection. But it was not the existence of the debate, nor the question whether there is a necessary connection between law and morality, that I was calling odd. Here is the passage in full; it identified the oddity only when and where it got to the point of using the word "odd" - in the passage's last sentence, for which the passage's preceding four sentences merely set the scene:

$[\mathrm{M}] \mathrm{y}$ work hitherto... fails to convey clearly enough the sheer oddity of the 'debate' that still dominates the construction of textbooks and distracts the attention of students. It is said to be a debate about whether there is any necessary connection between law and morality. It is supposed that until positivism cleared the air by its robust denial that there is such a connection, legal philosophy was entangled with moralizing and obfuscated by misplaced idealism. This supposition rests on simple inattention to the idiom of classic western philosophy, in which the propositions "An invalid argument is no argument," "A tyrannical constitution is no constitution," "A false friend is no friend," and "An unjust law is no law" presuppose and entail that arguments are not necessarily valid, constitutions are sometimes tyrannical, friends are not necessarily faithful, and law is not necessarily moral. But besides the inattention or ignorance, there is-and this is more interesting - the odd illogicality of supposing that the question whether there is 'any necessary connection' could be answered without conducting a moral inquiry.

Remember: the standard "positivist" claim is that "there is no necessary connection between law and morality." But if morality, properly understood, includes the proposition that it is necessary to have law, there is some necessary connection between law and morality-a morally necessary one. So those who make the standard "positivist" claim could not defend it without either establishing that there is no morality, or inquiring whether morality properly understood does include that proposition, an inquiry carrying them far outside the limits of their discipline as classic "positivists" such as Kelsen conceived it, and outside the positivist segment of the legal theory offered as positivist by such as John Gardner and Leslie Green. And morality, properly understood, does include that proposition, as I go on to argue in the paragraph following the one just quoted:

What does morality say about whether law needs to be moral? Obviously, the morality (moral belief) handed down in our civilization vigorously asserted the moral necessity (requirement, stringent moral need, and duty) that law be morally upright, and the viciousness of rulers (tyrants) who defy or ignore this necessity. More interestingly, the justified, true morality, as I have argued out in Natural Law and Natural Rights [360-1], takes the same position. It is morally necessary for responsible persons in community to arrange the community's affairs by introducing laws and adhering to the Rule of Law. It is morally necessary for citizens to treat their community's law as presumptively obligatory. ${ }^{48}$ 
That suffices to show the oddity I had in mind, the claim to be able to establish (or deny) that there is "no necessary connection between law and morality" without taking a stand on what morality requires, i.e., treats as normatively necessary.

\section{Is the Radbruch Formula the Right Thesis about the Consequences of Injustice in Law?}

The paragraph just quoted, about law's moral necessity, continues with some propositions that are relevant to-though not addressed to-one of Alexy's article's primary concerns, the "Radbruch formula" 49 thesis that injustice of a sufficiently serious degree renders a law legally invalid. For the paragraph just quoted went on:

And sound morality says something more about each of those morally necessary connections between law and morality. It says that the presumptive obligation of subjects is defeated (a) by countervailing moral responsibilities serious enough to make noncompliance just, and (b) by serious and relevant injustice in the formation or content of the law..$^{50}$

But the defeating of the presumptive moral ("legal-moral") obligation of subjects—who include judges and other officials—by "serious and relevant injustice..." does not suffice to settle the question of the unjust law's status in these subjects' concern to identify their moral responsibilities. For, as Aquinas regularly emphasized $^{51}$ and Natural Law and Natural Rights likewise maintains, there can be a "collateral moral obligation" to be seen to comply with, rather than defy, the

49 The passage usually counted as embodying the formula is this, particularly the part I have numbered [1]:

The conflict between justice and legal certainty may well be resolved in this way: [1] The positive law, secured by legislation and power, takes precedence even when its content is unjust and fails to benefit the people, unless the conflict between statute and justice reaches such an intolerable degree that the statute, as "flawed law" ["unrichtiges Recht"], must yield to justice. It is impossible to draw a sharper line between cases of statutory lawlessness and statutes that are valid despite their flaws. One line of distinction, however, can be drawn with utmost clarity: [2] Where there is not even an attempt at justice, where equality, the core of justice, is deliberately betrayed in the issuance of positive law, then the statute is not merely "flawed law," it lacks completely the very nature of law. For law, including positive law, cannot be otherwise defined than as a system and an institution whose very meaning is to serve justice. Measured by this standard ["Maßstab"], whole portions of National Socialist law never attained the dignity of valid law.

Gustav Radbruch, "Statutory Lawlessness and Supra-Statutory Law" Oxford Journal of Legal Studies 26 (2006): 7 (translated by Bonnie Litschewski Paulson and Stanley L Paulson). The original is Radbruch, "Gesetzliches Unrecht und übergesetzliches Recht," Süddeutsche Juristen-Zeitung 1 (1946): 105-108.

${ }^{50}$ Introduction, CEJF IV: 8. The paragraph concludes with an important thesis that need not be pursued here:

And it says that, whether similarly or by entailment, the moral necessity that rulers rule according to law is a necessity qualified by the moral necessity to take steps to preserve the community and its members against threats which the community has not forfeited its right to be defended from, including steps contrary to the law and even the constitution.

51 Summa Theologiae I-II q. 96 aa. 4c, 6c; II-II q. 68 a. 4c; NLNR, 360n, 476; Finnis, Aquinas: Moral, Political and Legal Theory (Oxford: Oxford University Press, 1998), 273-4. 
unjust law's demands whenever non-compliance with them would be unfair to others or in some other way morally irresponsible:

[I]f an unjust stipulation is, in fact, homogeneous with other laws in its formal source, in its reception by courts and officials, and in its common acceptance, the good citizen may (not always) be morally required to conform to that stipulation to the extent necessary to avoid weakening "the law," the legal system (of rules, institutions, and dispositions) as a whole. The rulers still have the responsibility of repealing rather than enforcing their unjust law, and in this sense have no right that it should be conformed to. But the citizen, or official, may meanwhile have the diminished, collateral, and in an important sense extra-legal obligation to obey it. ${ }^{52}$

My book then proceeded, immediately, to identify a number of relevant questions about unjust laws, questions that it had "passed over," i.e., not tried to answer. The last of these unanswered questions was:

...the question whether, in the aftermath of an unjust regime, the responsibility for declaring its unjust laws unjust and for annulling and undoing their legal and other effects should be undertaken by courts (on the basis that a court of justice-according-tolaw ought not to be required to attribute legal effect to radically unjust laws), or by retrospective legislation (on the basis that the change from one legal regime to the other ought to be explicit). ${ }^{53}$

In this way I both approached, but did not broach, issues addressed by the Radbruch formula, and also hinted that the formula may over-simplify matters by offering too short a short-cut through the forest. Was that hint warranted?

To address this in terms of "real" and "ideal" "dimensions of law" seems to me unhelpful. In particular, it confuses Is and Ought to assimilate (as Alexy does) the real dimension with "the principle of legal certainty," a principle in tension with "the principle of justice." 54 If the one principle is in tension with the other, they are in the same plane or realm, which in Alexy's terminology is the "ideal." More simply put: it is a principle of justice that we should generally have positive laws and have them (so far as is justly practicable) certainly identifiable, an identifiability that is secured, characteristically, by reference to social-fact sources of legal validity, such as enactment, precedential judicial rulings, etc. An observer's, purely descriptive legal theory cannot participate in an inquiry about the relation between "the principle of justice" and the principle of certainty; for such an inquiry is a moral inquiry about the requirements of justice in situations where the justicebased presumption that legal obligations entail moral obligations is defeated by the injustice inherent in a (purported) legal rule and the obligation it purports to

\footnotetext{
$52 N L N R, 361-2$.

53 NLNR, 362.

54 "Super-inclusive non-positivism gives absolute priority to legal certainty over justice when legal validity is concerned. In order to answer the question of whether such an absolute priority of the real dimension...": Alexy, "Some Reflections," 107 (and see, e.g., the whole of the last paragraph on p. 102).
} 
impose. What is said in the preceding sentence is, substantially, acknowledged by Alexy in his thesis (mentioned above) ${ }^{55}$ that from the observer's standpoint, the Radbruch formula is false. And, to repeat, Alexy is entirely right to hold that the central perspective for legal theory is the participant's, since "legal systems are possible without naked observers, but they are not possible without participants." 56

At this point, Alexy quotes a statement in Natural Law and Natural Rights; he quotes, that is, the second of the following two sentences from a set of paragraphs all dealing with "legal obligation in the intra-systemic sense" as distinct from "legal obligation in the moral sense (i.e., the moral obligation that presumptively is entailed by legal obligation in the intra-systemic or legal sense):" $" 57$

[S]ince there is little point in meditating about the legal-obligation-imposing force of normative meaning-contents which are not treated as having legal effect in the principal legal institutions of a community (viz. the courts), it is idle to go on asking the question in this sense (the second of the four listed [on p. 354]) after ${ }^{58}$ the highest court has ruled that in its judgment the disputed law is not unjust or, if unjust, is none the less law, legally obligatory, and judicially enforceable. It is not conducive to clear thought, or to any good practical purpose, to smudge the positivity of law by denying the legal obligatoriness in the legal or intra-systemic sense of a rule recently affirmed as legally valid and obligatory by the highest institution of the "legal system." 59

On this second sentence, Alexy comments:

From the point of view of a participant... Finnis's separation of the legal obligation from the moral obligation must be rejected. After the collapse of a regime that ruled on the basis of extremely unjust laws, the question of whether these laws and the decisions based on them were null and void from the beginning may be of the utmost importance for the protection of the human rights of the regime's victims. This suffices as a "good practical purpose."

55 See text at $\mathrm{n} 13$ above.

56 Alexy, "Some Reflections," 109.

57 NLNR, 354.

58 [Meaning "immediately after." I had in mind Ronald Dworkin's thesis, articulated in the Dworkin-Raz-Finnis seminars in Jurisprudence and Political Theory in the years before NLNR, that even immediately after Plessy v. Ferguson (1896) 193 U.S. 537 had decided otherwise, laws dividing races between "separate but equal" facilities were invalid-not part of US law-because unjust by the standards of US law morally understood.]

59 NLNR, 357. The extent of the 2013 article's misunderstanding of the passage is indicated by points enumerated as (a) and (b) in the parenthetical sentences immediately following those just quoted, a parenthesis which concludes the paragraph:

(Austin's concern to make this point, in the 'hanging me up' passage, was quite reasonable. What was unreasonable was his failure to acknowledge (a) the limited relevance of the point, and (b) the existence of questions which may be expressed in the same language but which are not determinately answerable intra-systemically.) 
After two further sentences that I think can be omitted here (but readers can consult), concerning my position's over-simplification of issues, as something avoided in the "more complex" Radbruch formula, Alexy concludes:

Finnis's distinction between a legal ${ }^{60}$ and a moral sense of "legal obligation" is not an adequate alternative to the Radbruch formula. It fails to give sufficient weight to the ideal dimension in cases of extreme injustice.

Clearly, Alexy's whole comment at this point is to some extent at cross-purposes with the pair of sentences from which he quoted the second. For the first of those sentences made clear that what the passage was directly addressing was the situation during, not after, the persistence of a regime, while the norms of justice "are not treated as having legal effect in the principal legal institutions of a community" or, as I put it a couple of sentences later, "when one is confident that the legal institutions of one's community will not accept that the law in question is affected by the injustice one discerns in it."

Next we should notice that Alexy's comment tames the Radbruch formula, which purports to address the legal situation during as well as after the unjust regime's persistence. ${ }^{61}$ If Alexy really is content to confine the formula's moral and legal relevance to the post-collapse situation, ${ }^{62}$ nothing he says entails rejecting what he quoted me as saying. Indeed, he is (if so) implicitly accepting rather than rejecting this element in my position.

In fact, my position, so far from failing to "give sufficient weight to the ideal dimension," attributes more weight (so to speak) to the "ideal dimension" than the Radbruch formula attributes. So far from being "super-inclusive non-positivism," as Alexy says it is, my primary position is closer (though it only approximates) to what he calls "exclusive non-positivism," the position he calls in his 2002 book "the strong connection thesis" (strongly correlating injustice and legal invalidity in the moral sense of "legally (in)valid"). ${ }^{63}$ There he also says it is a

60 [This sense of "legally obligatory" was defined, NLNR, 354 thus:

(ii) legal obligation in the intra-systemic sense ('legal obligation in the legal sense') in which the practical premiss that conformity to law is socially necessary is a framework principle insulated from the rest of practical reasoning.

Note that the whole discussion in NLNR focuses on (four) senses of "legally obligatory" rather than on "legally valid." Kelsen's struggles with the latter term showed clearly enough that any interesting sense of "legally valid" include "legally obligatory". But NLNR did not tackle the further significance of the legally valid as a source of authority and disqualifications, and of permissions and licenses or excuses, and so forth. JMF]

${ }^{61}$ Indeed, was not a primary post-War objection of Radbruch's to "legal positivism" that it disabled German lawyers and legal theorists from resistance to Nazi laws from the outset? See "Weber, Objectivity, and Legal-Rational Authority," CEJF IV: 221; but the issue is complex and the scholarly literature extensive.

${ }^{62}$ In The Argument from Injustice, he says (56): "Radbruch's formula is of practical significance above all after the collapse of a rogue regime." And (50): "Once a rogue state is successfully established, legal concepts may no longer have much effect. Only after the collapse of such a state are essential differences between the positivist and the non-positivist evident."

${ }_{63}$ Note, incidentally, that Alexy's 1992/2002 book, at 46-7, gives some credence to (while falling short of adopting) an argument of Kelsen and Hoerster, and of Hart (The Concept of Law, 210 [2056], that must be one of the most absurdly sophistical in the history of philosophy: that someone who holds that "unjust laws are not laws" must believe, or at least teaches, that there are no unjust laws-in 
position that "no serious non-positivist" defends. ${ }^{64}$ (It is the position defended by Aquinas and his followers, who are neither rare nor frivolous; and today, as Alexy notes, by Beylefeld and Brownsword, whose thesis on the point is highly praised by Stanley Paulson. ${ }^{65}$ ) My position, as I begin unfolding it on the same page of $N L N R$, culminates in the thesis that:

For the purpose of assessing one's legal obligations in the moral sense, one is entitled to discount laws that are "unjust" in any of the [four or five] ways ${ }^{66}$ mentioned. Such laws lack the moral authority that in other cases comes simply ${ }^{67}$ from their origin, "pedigree," or formal source. In this way, then, lex injusta non est lex and virtutem obligandi non habet [does not have authority to bind], whether or not it is "legally valid" and "legally obligatory" in the restricted sense that it (i) emanates from a legally authorized source, (ii) will in fact be enforced by courts and/or other officials, and/or (iii) is commonly spoken of as a law like other laws. ${ }^{68}$

My above-recalled point about possible collateral moral obligations to comply with these purported and unjust laws follows shortly after this passage, a passage, be it noted, asserting that from the participant's point of view at its full stretch the unjust law non est lex, that is, is not law and does not impose "legal obligations in the moral sense." It is clear, then, that my position is not less but rather more

Alexy's phrase, such a person (holding the "strong connection, exclusive non-positivist" position) "uncritically legitimates" even unjust laws! On this muddle, in Hart's version, see NLNR, 364-5.

${ }^{64}$ The Argument from Injustice, 52, where he is referring to both of two positions "[i] a strong connection thesis, that is, those variants [of non-positivism] according to which every injustice leads to the forfeiture of legal character ... [ii] [a position according to which] every person is given the authority, appealing to his own notion of justice, to refuse to comply with statutes..." His dismissive comment is sound in relation to [ii], since those who hold position [i] are not conferring or attributing authority to anyone, let alone authority predicated on beliefs-sound or unsoundabout justice and injustice.

65 See $\mathrm{n} 78$ below.

${ }^{66}$ NLNR, 360: "stipulations made for partisan advantage, or (without emergency justification) in excess of legally defined authority, or imposing inequitable burdens on their subjects, or directing the doing of things that should never be done..."The list is essentially Aquinas's: Summa Theologiae I-II q. 96 a. 4c; see NLNR, 352-4 with 367 (citing also St German and Suarez).

67 [In the context of $N L N R$, no-one will misunderstand this as trying to get an Ought from an $I s$; these social-fact sources have the moral authority they do by virtue of being taken with moral premises extensively articulated over the previous 300 pages of the book.]

${ }^{68}[N L N R, 360-1$ (emphasis added in the first line).] Note: it is true, as Alexy, "Some Reflections,"105, says, that $N L N R, 364$, takes up the famous sentence "'an unjust law is not a law: lex injusta non est lex," but Alexy has missed my adoption of lex injusta non est lex into my own argument on p. 361. In the later of these two passages, I am considering not so much the moral rights and duties of judges and others confronted with unjust laws, but rather the place of the slogan in a general theory of law. Alexy's rendering at p. 105 of the observations at NLNR, 364 confuses matters by interpolating a line of thought not deployed by me until long after $N L N R$ (the comparison of "is not a law" with "... is not an argument"):

According to Finnis, in the first edition of Natural Law and Natural Rights, this statement, because an unjust law is a law just as an invalid argument is an argument ["Introduction," CEJF IV: 7], is either "pure nonsense, flatly self-contradictory or else is a dramatization of the point more literally made by Aquinas when he says that an unjust law is not law in the focal sense of the term 'law' [i.e. simpliciter] notwithstanding that it is law in a secondary sense of that term [i.e. secundum quid]." [NLNR, 364]

The fifteen words after "this statement" should be excised, if one is to understand the position as articulated at NLNR, 364 . 
complex than Radbruch's, and gives all the weight that anyone could reasonably give to the "ideal dimension" (not excluding the "principle of certainty" accurately regarded as one principle of justice among others).

The Alexy-Radbruch position over-simplifies in two ways, by holding that (i) there is a point (perhaps fuzzy) at which the severity of a legal rule's injustice, being "intolerable," ${ }^{9}$ carries that rule over the threshold, and (ii) below the threshold the rule is simply legally-valid and above the threshold it is simply legally-invalid, null-and-void. Here we should observe, however, that Alexy's 2013 article offers a refinement or complexification, already briefly noted. ${ }^{70}$ Moral defectiveness below the threshold still results in legal defectiveness (short of invalidity - here we meet his "qualifying" rather than "classifying" connection between law and morality). If it did not so result, he says, "it would be difficult to explain why a higher court-independently of what the positive law says-has the legal power to set aside the unjust decision of a lower court in a case in which this unjust decision is every bit as compatible with positive law as would a just decision [have been or be]."71 Whatever one may think of that argument, the refinement or complexification suggests that the main Alexy-Radbruch all-or-nothing, valid-or-invalid thesis rests on an unsound assumption: that the morally significant consequences of significant injustice (severe or not) in law's making or content are to be articulated as if, at some point (i.e., in relation to some rules of sufficiently severe injustice), (A) they could all be appropriately identified by reference to the standard legal technique of drawing a bright line between the valid and the invalid; and (B) this bright line is to be sought as a truth about law.

The unsoundness of this two-part assumption is illustrated by the very case to which Alexy's 1992/2002 book gives pride of place in expounding "the practical significance of the debate" (title, chap. 2), the decision of the Federal Constitutional Court of Germany in 1968 that the German law of 25 November 1941, stripping non-resident Jews of their German nationality (and expropriating their property "to be used to further aims associated with the solution of the Jewish problem"), was void ab initio despite "having been observed over a number of years." 72 This decision was said by the Court itself to be based on "the possibility of revoking the legal validity of National Socialist 'legal' provisions when they conflict with fundamental principles of justice so evidently that the judge who elected to apply them or to acknowledge their legal consequences would be administering lawless (Unrecht) rather than law" (emphasis added) ${ }^{73}$ But this line or argument is plainly problematic; its premise, just articulated, is

69 The Argument from Injustice, 40, 47.

${ }^{70}$ See above, n3. Similarly, in slightly different terminology, The Argument from Injustice, 36, 127.

${ }^{71}$ Alexy, "Some Reflections," 104.

72 BVerfGE 23 (1968) 98, 106 quoted by Alexy, The Argument from Injustice p. 6. On the case and the whole problem see also Oppenheimer v. Cattermole [1976] Appeal Cases 249 and F.A. Mann, "The Present Validity of Nazi Nationality Laws," Law Quarterly Review 89 (1973): 194-209.

73 Ibid. 
simplistic. To go no further: the German Basic Law (Constitution) of 23 May 1949 was not "administering Unrecht" when it provided in Art. 116(2) that

Former German citizens who, between 30 January 1933 and 8 May 1945, were deprived of their citizenship on political, racial, or religious grounds, and their descendants, shall be regranted German citizenship [nationality] on application. They shall be considered as not having been deprived of their German citrizenship if they established their domicile in Germany after 8 May 1945 and have not expressed a contrary intention.

The Constitutional Court in 1968 held that Jewish Germans subject to the 1941 law who died before 23 May 1949-when Art. 116 took effect-were German nationals "unless they displayed the intention not to retain German nationality"; and those who survived beyond the enactment of Art 116 in 1949 (a) did not lose their German nationality but (b) are not treated by the German state as German unless they apply for citizenship/nationality or become domiciled in Germany. The distinction between (a) and (b) is highly elusive. ${ }^{74}$ And the effect of Art. 116 as interpreted by the 1968 decision is that a Jewish German who (because of the attributed invalidity or judicial revocation $a b$ initio of the Nazi law) did not cease to be a German in November 1941 nevertheless did cease to be a German on 23 May 1949 unless he either applied then (or later?) to become a German national again or took up residence in Germany (even if later?). ${ }^{75}$ And this loss of nationality in 1949 was precisely because such a person was someone dealt with by the Nazi law [or "law"] of November 1941, a law considered in 1949 and 1968 as a fact with that significance because it had once been legally proposed and treated as a legal reason. The provisions of Art. 116, as interpreted by the Court in 1968, are neither a truth of legal philosophy nor an entailment of such a truth, but are instead a more or less just compromise, albeit not the only just compromise possible, as a response to the facts unjustly created by or resulting from the

${ }^{74}$ As is observed by Mann (a strong supporter of the 1968 decision and its Radbruchian "naturallaw" basis) in "The Present Validity of Nazi Nationality Laws," 200, and by Lord Cross (with Lords Hodson and Salmon) in Oppenheimer v. Cattermole [1976] A.C. at 271G.

75 See Oppenheimer v Cattermole, 271D-272A; at 273-4. Lord Cross holds that-as a matter of German law as interpreted by the Federal Constitutional Court in 1968-the appellant resumed German nationality by application under Art. 116(2) he made some time after 1969, having lost it in 1949. Lord Cross also stated (obiter but with the support of Lords Hodson and Salmon) that English law should refuse to "recognise as law at all" a "law [that] ... constitutes so grave an infringement of human rights" (278B), and that (278D) "it surely cannot be right for the question whether the decree [of November 1941] should be recognized or not to depend on the circumstances of the particular case." But against that last thought, Lord Hailsham responds (263D-G) that "with due respect to that argument, foreign municipal law is a question not of law but of fact, and the only way known to English law of disregarding an unpleasant fact is to create a legal fiction that it does not exist... [W] here [such fictions serve a useful purpose], among the criteria would certainly be included the effect of the proposed fiction on individuals... It may well be that English law will not give a single and unequivocal answer to the problems raised by the unjust and discriminatory legislation of a foreign country ..." (263D-E). As Lord Hailsham also noted (263F): "American law appears to have fallen short of rejecting the National Socialist decree [of November 1941], at least when the consequence of doing so would have been the internment of the propositus [see United States ex rel Schwartzkopf v. Uhl (1943) 137 Fed. Rep. 2d 898]." In short, those who died before May 1949 (or May 1945) retained their nationality unless they renounced it; those who lived beyond 23 May1949 lost it as from November 1941 unless they reclaimed it on or after 23 May 1949. 
1941 enactment-injustices that would only be multiplied if the existence of that law were simply denied, as the Radbruch formula on its face does.

It is better, I think, to proceed on the assumption that the moral consequences of significant injustice in the making or content of purportedly and intra-systemically valid legal rules are to be assessed by reference to all the considerations of justice that bear on the situation in which the question of the rule's application (present or past) arises for consideration. As Natural Law and Natural Rights concluded:

Much can be said on such questions, but little that is not highly contingent upon social, political, and cultural variables. It is universally true that one has an absolute (liberty-) right not to perform acts which anyone has an absolute (claim-)right that one should not perform (see VIII.7). But beyond this, one should not expect generally usable but precise guides for action in circumstances where the normally authoritative sources of precise guidance have partially broken down. ${ }^{76}$

In short, the Radbruch formula does not state a conceptual necessity, and is somewhat rough and ready as a principle for resolving the consequences, within legal systems, of injustice in the making or content of prior or current purported, formally valid rules of law. It is not a truth about law, a truth of the philosophy of law (legal theory), even if in many cases its adoption and application as a rule of thumb-an "expedient concept," as Alexy says"7-works reasonably well in resolving questions arising in legal practice from such injustice. The relevant truth of the philosophy of law-a theory which includes the parts of (critical, true) morality that bear on the making and application of laws-is, rather, that (1) any significant injustice in making or content deprives a law or legal decision of that moral respect-worthiness that every formally or intra-systemically valid law and decision within a by-and-large just legal system has (and should be acknowledged by courts and other officials and subjects to have, even when the law or decision could reasonably and perhaps more fittingly have been significantly and incompatibly different); and (2) laws and decisions so deprived may nonetheless be such that in some or many particular situations they should be applied while in some or many other situations they should not.

Since these two propositions of legal-moral theory hold good for a court, their combined effect approximates to Alexy's 2013 thesis that significant injustice, even when not severe or intolerable, renders intra-systemically valid rules of law legally defective. ${ }^{78}$ We may say: Unjust laws, despite their intra-systemic validity, are not reasons of the authentically legal kind that law should exist to create; but the fact that others treat these laws as legally valid or demand that they be treated as such is an important fact, to be taken into account when deciding what are one's responsibilities as a participant in the legal order of one's society. We might then adapt Alexy's thesis to say that significant injustice renders intra-systemically valid rules of law voidable by courts, at least if voidability is taken to be pro tanto,

${ }^{76} N L N R, 362:$ "such questions" refers to the list of untackled questions about consequences of injustice in law, finishing with the question quoted above at $\mathrm{n} 53$.

77 See 22 above, referring to "expedient or adequate concept-formation."

78 Alexy, "Some Reflections." 104. 
i.e., relative to certain kinds of legal context and certain classes of persons, rather than in all-or-nothing fashion. Voidability in this sense builds in-that is, a responsible decision when and in what respects to declare a rule void is subject to-all the moral considerations urging restraint and discrimination in, and on the occasion of (and after), setting aside (or judging inapplicable) the presumption of moral obligatoriness or other sorts of moral applicability. Restraints and discriminations of this sort are what Aquinas is all too briefly gesturing towards in his repeated caveat about (in my terminology) possible collateral moral obligations not to be seen to set aside law, even unjust law.

From a moral-philosophical starting-point widely differing from Aquinas's or mine, Beylefeld and Brownsword elaborate such restraints and discriminations, as establishing that in certain situations there will be a "collateral synthetic obligation" to comply with an immoral legal rule (upheld in the courts), such that subjects ought, "all moral things considered," to comply with that legal rule even though, because of its injustice (not necessarily severe or intolerable) it is a rule that itself can no longer be rightly said to impose an obligation (of the kind that we need law to impose-the legal-moral obligation central to the central case of legal theory). ${ }^{79}$ On this thesis, which in substance (though perhaps not in intent and genealogy) is an elaboration and enrichment of Aquinas's, Alexy comments:

This can be accepted with respect to its results but not with respect to its construction, which can be considered as a paradigmatic case of an auxiliary construction that attempts to treat the consequences of a mistake instead of curing the disease itself. The alternative construction of inclusive non-positivism that, from the beginning, gives more weight to the factual dimension of law vis-à-vis its ideal dimension is not only preferable for reasons of simplicity, but also with an eye to the fact that it captures better the nature or essence of law. ${ }^{80}$

If there is a mistake, I think it is in Alexy's "inclusive non-positivism" in so far as it is conceived to be a truth about the nature or essence of law. Two signs of this are present in the last sentence quoted: the idea that what is at stake here is a "construction"; and the idea that one could weigh by reason such incommensurables as "ideal" and "real/factual" "dimensions."

The result of these reflections could be summarized by saying that (1) since a sound legal philosophy/theory incorporates the observer's perspective as a component of the reasonable participant's perspective, the injustice of a law recognized by courts and officials as intra-systemically valid law has no effect on that validity, however intolerable the injustice; and in this respect a sound legal theory is in Alexy's schema "super-inclusive" (without, however, that label's pejorative connotation of excessiveness); (2) since a sound legal philosophy/theory is done from the reasonable participant's perspective, any significant injustice in the making or content of the law deprives it of its legal-moral validity and its entitlement to the benefit of the presumption of moral obligatoriness, and in this respect

79 See Stanley Paulson's approving summary of their position, cited by Alexy, "Some Reflections," $107 \mathrm{n} 60$.

${ }^{80}$ Alexy, "Effects of Defects-Action or Argument?," Ratio Juris 19 (2006): 171, commenting on Paulson's summary of the position (see n79 above). 
a sound legal theory is in Alexy's schema "exclusive"; but (3) since the reasonable participant in legal order recognizes (a) the primacy of the common good and the importance of positive law and of its application in practice to upholding that common good and the human rights included in common good and (b) the many bad side-effects that come from non-compliance with law especially by persons who systematically benefit from the law's existence and regularity of application, there can be many occasions when courts and many other officials and citizens ought not to depart observably from an intra-systemically valid law notwithstanding its injustice and lack of inherent legal-moral validity and obligatoriness; and because the frequency of these occasions will often be inversely proportional to the law's degree of injustice, there will often be an approximate convergence in the application of this line of thought with the application of the Radbruch formula; and so far forth, "inclusive non-positivism" may as a rule of thumb tend to converge, in its application, ${ }^{81}$ on the true position in legal philosophy.

81 But this summary (like NLNR's account of the "collateral obligation") over-simplifies, because the problem of what to do with unjust laws varies according to the time at which arises, and the parties in respect of whom it arises, and the position and role of the persons faced with the problem; see text and $\mathrm{n} 75$ above. 